\title{
Scrum Methodology as an Effective Scaffold to Promote Students' Learning and Motivation in Context-based Secondary Chemistry Education
}

\author{
Johannes Vogelzang ${ }^{1,2^{*}}$, Wilfried F. Admiraal ${ }^{2}$, Jan $\mathrm{H}$. van Driel ${ }^{3}$ \\ ${ }^{1}$ Greijdanus College, Zwolle, THE NETHERLANDS \\ ${ }^{2}$ Leiden University Graduate School of Teaching, Leiden University, THE NETHERLANDS \\ ${ }^{3}$ Melbourne Graduate School of Education, The University of Melbourne, AUSTRALIA
}

Received 23 April 2019 • Revised 26 May 2019 • Accepted 9 June 2019

\begin{abstract}
Context-based approaches aim at increasing students' learning and motivation. However, students perceive its complexity often as overwhelming, causing frustration and disengagement. Thus, there is a need for innovative teaching methods to scaffold students in context-based education. Two perspectives are used to argue that Scrum methodology, a project management framework, is a promising candidate.

First, its features are described and subsequently connected to six well-known scaffolds from the motivational literature. This exploration showed that implementation of Scrum methodology might lead to improvements of students' motivation and an increase in cognitive and metacognitive learning achievements.

Secondly, an empirical pilot study was conducted. Three experienced chemistry teachers implemented Scrum methodology in their chemistry lessons. Interviews revealed that Scrum methodology visualized students' learning process and progress. Two teachers reported stable and even better learning outcomes. In addition, they perceived that their students showed increased engagement. However, one of the participating teachers reported student resistance towards parts of the Scrum methodology as well as organizational issues. This teacher emphasized that Scrum methodology is in itself rather complex and that implementation is not an easy job. Although the pilot study suggests that caution is urged, its implementation might give new momentum to reinforce context-based approaches.
\end{abstract}

Keywords: context-based approach, innovative teaching, scaffolding (teaching technique), Scrum methodology, teaching secondary chemistry

\section{INTRODUCTION}

There is a need for instructional innovations in context-based approaches. Originally, context-based approaches have been implemented in secondary chemistry education to address several challenges, including, motivational problems among students, perceived irrelevance of chemistry and fragmented curricula (Gilbert, 2006). Contextbased approaches are thought to be motivating for students, contributing to active student involvement, and stimulate integration of knowledge. Implications of context-based approaches were described thoroughly in two special issues of the International Journal of Science Education (Pilot \& Bulte, 2006; Sevian, Dori, \& Parchmann, 2018). Although effects regarding students' interest and perception of relevance have been found (Savelsbergh et al., 2016), findings on students' conceptual understanding are diverse and need further investigation (Bennett, 2017).

(c) 2019 by the authors; licensee Modestum Ltd., UK. This article is an open access article distributed under the terms and conditions of the Creative Commons Attribution License (http://creativecommons.org/licenses/by/4.0/).

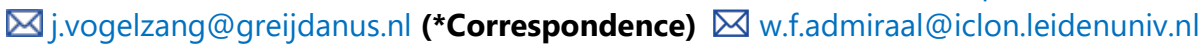

\.vandriel@unimelb.edu.au 


\section{Contribution of this paper to the literature}

- Context-based approaches are developed to enhance students' learning as well as their motivation. Although promising examples are published, these approaches are often overwhelming for students, causing frustration and disengagement. Students might benefit from new instructional strategies for context-based approaches.

- Scrum methodology, a project management framework used in business, provides ceremonies, roles and artefacts that structures students' learning process and visualizes students' progress. Knowledge whether the implementation of Scrum methodology enhances students' learning and motivation is lacking.

- Key characteristics of Scrum methodology are connected to six scaffolds from the motivational literature, suggesting that its implementation might increase both students' learning and their motivation.

- Experiences of three teachers underline the potential of Scrum methodology in strengthening students' learning in context-based learning environments.

A typical context-based approach starts with a real-world question, strongly connected to both the personal lives of students and the underlying chemistry concepts (Gilbert, 2006). Students collaborate in small groups and carry out the following tasks: 1) planning, 2) find useful information, 3) perform experiments and exercises, 4) synthesize information to answer the central question, 5) build arguments in support of the proposed solution. Context-based approaches invite students to direct, monitor and reflect on their learning so that they become selfregulated learners.

Yet, creating and implementing a context-based learning environment turns out to be difficult. Factors that facilitate or hinder implementation include that teachers' beliefs about teaching and learning must be in line with the rationale behind context-based learning. In addition, teachers should possess skills necessary to implement appropriate and well-designed context-based teaching materials (Vos, Taconis, Jochems, \& Pilot, 2016).

However, just like teachers, students also experience difficulties with context-based learning. Complex, realworld assignments can be overwhelming, causing uncertainty and frustration how to achieve the desired objectives (Quintana et al., 2004). Using unfamiliar learning strategies to solve real-world assignments and transferring the underlying chemistry concepts to new situations set high demands on students (Parchmann, Broman, Busker, \& Rudnik, 2015, p. 260). Combining these challenges with collaboration and communication issues among team members clarifies that implementation of context-based approaches can be a rather precarious adventure for both students and teachers. King and Ritchie (2012) emphasized that perceived implementation issues in context-based learning are comparable with challenges described for problem-based learning. Other scholars described similar implementation problems with other student-centered learning environments, such as project-based and inquiry based learning (Cunningham, 2016). To overcome these challenges students' learning process should be guided, structured and focused (Mayer, 2004, p. 17). Although scaffolds to support the implementation of project-based learning were presented in the educational literature (Hmelo-Silver, Duncan, \& Chinn, 2007) there is still a need for innovative tools to guide students (Harris \& Rooks, 2010). Mergendoller, Markham, Ravitz, and Larmer (2006, p. 609 ) suggested that it would be worthwhile to study and evaluate project management methodologies, procedures and tools developed in business or industry to improve problem-based learning in schools.

This research focused on Scrum methodology, a widely used and rather successful project management framework. Its ceremonies, roles and artefacts are described thoroughly and subsequently connected to a contextbased chemistry course on redox-chemistry. Subsequently, from a theoretical point of view, its ceremonies, roles and artefacts are connected to a motivation theory, showing that Scrum methodology provides scaffolds beneficial to promote both students' learning and motivation. These theoretical insights are illustrated by experiences of three teachers, who implemented Scrum methodology in their redox-chemistry classrooms.

\section{SCRUM METHODOLOGY}

Etymologically the word scrum is derived from scrummage, which refers to a group of individuals. Nowadays a scrum is a method of restarting play in rugby. It involves a group of players packing closely together with their heads down. Each player has his own specific position and task in the scrum. Together they develop an enormous power, which they use to gain possession of the ball. Thus, a scrum can be considered as metaphor of a powerful team, with a clear goal (Schwaber \& Sutherland, 2017).

The original meaning of scrum is broadened. Scrum is a powerful management framework used in companies for organizing complex projects. Scrum methodology refers to an iterative process for managing product or software development (Scott, Rodríguez, Soria, \& Campo, 2016). Scrum has, if diligently applied, several benefits: reduced costs, improved return on investment, fast results, delighted customers, more joy and confidence to succeed in a complex world (Rubin, 2012, p. 6). 
Scrum methodology consists of three major tenets: transparency, inspection and adaptation (Schwaber \& Sutherland, 2017). Transparency refers to clearly defined goals and the visibility of the processes involved to reach them. Inspection concerns to frequent reviews to check team progress. Adaptation refers to adjustments that can be made during the process in accordance with changing circumstances or when an intermediate product does not meet with desired requirements.

The tenets of Scrum methodology are fostered by roles, ceremonies and artefacts. The role of the product owner is of central importance. The product owner initiates the project, clarifies its objectives and provides the scrum team with a list of requirements: the product backlog. The product owner guides the scrum team and monitors its progress. A typical scrum team consists of four members, of which the scrum master plays a key role as linking pin. Activities of a scrum master include communicating with the product owner, removing hindering obstacles and smoothing progress by stimulating mutual communication among team members. Team members bring their own preferably complementary, skills and qualities to the scrum team. Enhancing diversity among team members promotes accountability, responsibility and ownership, because team members are appreciated due to their personal and specific qualities.

Scrum teams use ceremonies to keep on the right track. Every day the team organizes a stand-up meeting in which progress and planning are discussed. Major advantage of these daily meetings include that potential problems are identified in an early stage. Releasing an intermediate product within two weeks is another key characteristic. These two weeks' periods, or sprints, are finished with a review ceremony in which the product owner comments the quality of the intermediate product. During the review ceremony, adjustments to improve the quality can be made. Product owner and team use the feedback to update their product backlog. The review ceremony is immediately followed by a retrospective, in which the team members address collaboration issues and renew their commitments. Then a new sprint cycle starts until the ultimate goal of the project is reached.

Scrum teams use artefacts to visualize their progress. The product backlog, consists of items necessary to achieve the project's aim. These items are prioritized and awarded with points, providing an overview of what is expected during a sprint. Descriptions of items are described on Post-It notes and attached to a scrum board, which is a transparent tool to see at a glance what has been finished and what has to be done. A typical scrum board includes three columns and a burndown chart. The first column comprises Post-It notes with items 'to do'. The second column consists of Post-It notes with items team members are working on. Title of this column is 'doing' and the last column contains Post-It notes with items that are 'done'. Putting a Post-It note in the column 'done' is only allowed when it meets with the agreed 'definition of done'. The burndown chart is a graph representing the progress of the project and the amount of work left to do. Thus, Scrum methodology creates an environment that starts with a common objective, stimulates mutual collaboration, and encourages feedback. These characteristics reflect many of the principles of context-based approaches (Nentwig, Demuth, Parchmann, Ralle, \& Gräsel, 2007), including that students provide feedback to each other while working in small collaborative groups on an illstructured, yet clear and transparent, objective. But that is not all. Scrum methodology provides additional ceremonies and artefacts that keep students on track, decrease the complexity of the project, and help students to become self-regulated learners. Therefore, implementing Scrum methodology as scaffold in overwhelming contextbased approaches might be an effective response to perceived challenges.

\section{Scrum Methodology in a Secondary Chemistry Classroom}

The module on Takeaway Energy is a typical example of a context-based approach. It focusses on redoxchemistry, often experienced as a difficult and demotivating topic (De Jong \& Treagust, 2003), and was developed for students of grade 11. The module consists of three stages complemented by a challenging, final assignment. The first stage of the module is based on a recognizable context, starting from students' lives, as it focusses on the use of (rechargeable) batteries. These rather small, ready to use, and portable forms of energy have many applications, including students' smartphones and other electric devices. Given the fact that smartphones play an important role in students' lives, this context attributes to students' individual interest, which plays an important role in their motivation to study chemistry. In addition, the context helps students to see the value of accompanying learning activities.

In the second stage, students are challenged to work on and understand the underlying chemistry concepts, according the 'need-to-know' principle. They are invited to learn how chemical energy is transferred to electric energy and how they can predict these reactions. In the third stage they will get insight in environmental issues connected to the use of batteries. Finally, students are invited to design and build their own battery, a Galvanic cell, for instance in the form of a toy car powered by a citric acid battery.

Scrum methodology was implemented in the classroom to guide the students through the different stages of this context-based approach. At the start of the lesson series the teacher, in his role as product owner, explained the 


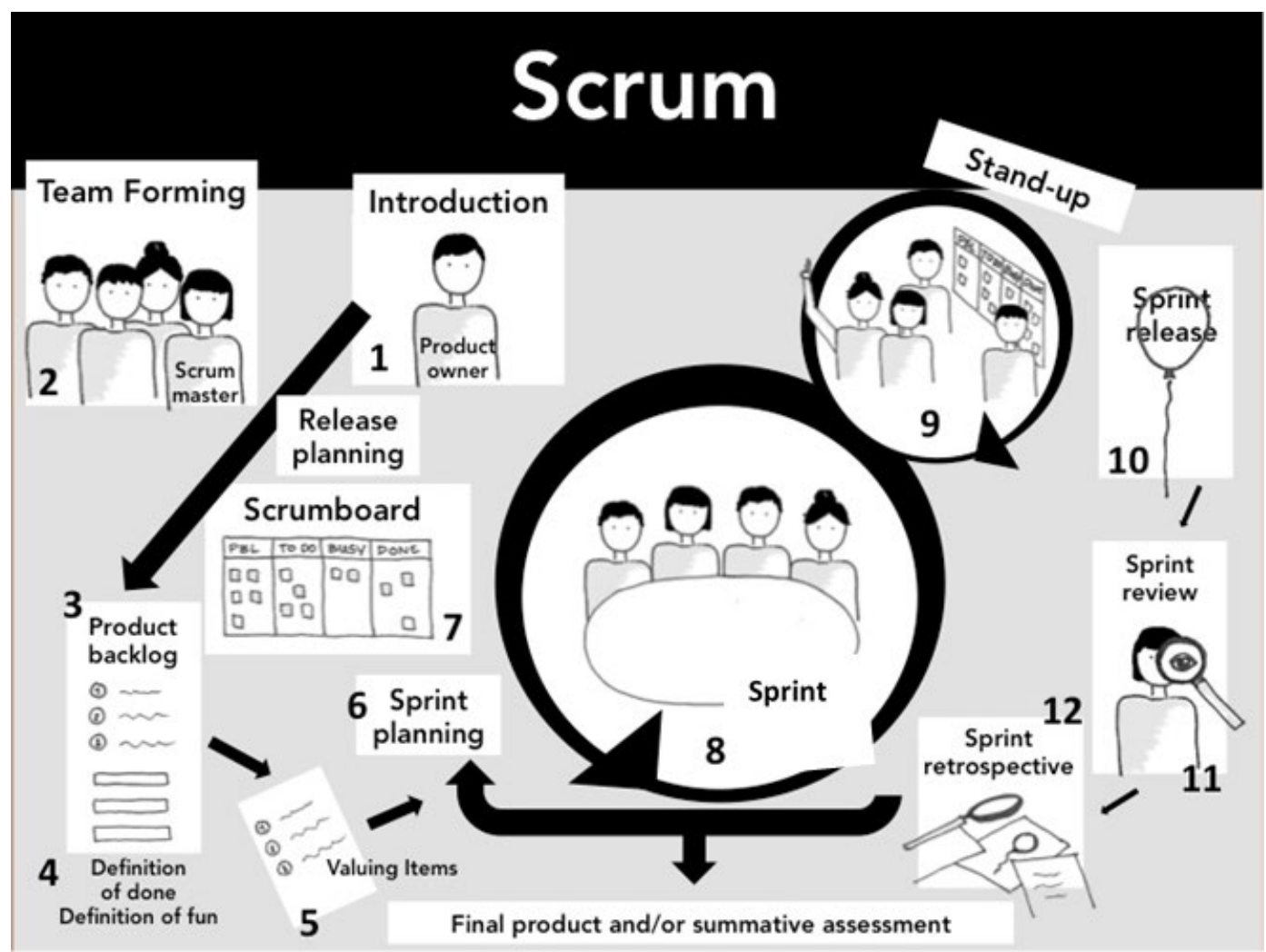

Figure 1. Overview of Scrum methodology

learning objectives and presented the central question of the project. In scrum terms, the teacher took his role as product owner and presented the project's ultimate goal to the students (Figure 1, step 1).

In this particular case, students should design and build a Galvanic cell, as a model for a battery. Connecting the context of batteries to the social environment and personal lives of students was the first step to create engagement. As product owner, the teacher highlighted the important function of batteries in smartphones, electric cars and as potential storage device of energy produced by sunlight.

The introduction is followed by a classroom discussion in which students and teacher reflect on the (dis)advantages of Galvanic cells. After having finished discussions related to the content and objectives of the project, a ceremony started in which teams of four students are formed (Figure 1, step 2).

First, students received a list containing personal qualities they could bring to their team. Examples are: planning qualities, arithmetic, or the ability to write clearly. They checked three boxes of the list and handed over their form to the product owner. Then at least a quarter of all students were nominated by their classmates as scrum master. Students, who accepted their nomination, became scrum master and their first task was to compose a balanced team with complementary qualities. After distributing all forms, they read the names of their team-mates aloud. A student whose name was mentioned, joins his scrum master.

During the project, the scrum masters played a crucial role. Typical responsibilities are: initiating dialogue among team members about project issues and communicating with the product owner.

The product owner provided each scrum team with a product backlog in which exercises, experiments and deadlines were presented (Figure 1, step 3). This product backlog can be seen as a compass to the final destination, i.e. the ultimate objective of the project. The product backlog on redox-chemistry covers a period of approximately six weeks. Every week students participated in two lessons of 60 minutes.

The newly formed teams gathered to make their first arrangements. Firstly, they invented a group name, and agreed on their own definition of fun, and their own definition of done (Figure 1, step 4). Making up their own group name and definitions of fun and done contributed to feelings of ownership and autonomy. In the definition of fun, they describe how they want to collaborate in a pleasant way to enjoy the project. A typical example of a definition of fun is: every lesson we have a short break in which we tell each other at least one joke. An example of a definition of done is: we will comment all exercises and experiments of all group mates.

The next phase included valuing all exercises, experiments and assignments with points (Figure 1, step 5). Scrum teams discussed the difficulty of an assignment. If they weighed up an exercise as average it was rewarded 
with 2 points. An easy assignment was awarded with 1 point and a more complicated task was allocated with up to 5 points. Over time, groups improved in making educated guesses to value the assignments. Finally, all points for the assignments of the upcoming two weeks were added together. The two-week period formed a sprint (Figure 1, step 8) and consisted of approximately 50 points.

These points were helpful in the planning phase (Figure 1, step 6). Scrum teams became aware of how many points they had to 'burndown' in two weeks. All assignments, accommodated with points, were written on Post-It notes. Planning of all exercises, experiments and assignments was made visible on a scrum board, which - in its most simple form - comprises four columns: 1) product backlog with all items; 2) to do; 3) doing; and 4) done. An overview of all activities and their progress could be seen on the scrum board by both the scrum team members and the teacher (Figure 1, step 7).

Although the introduction of the project, forming of scrum teams and planning of activities were timeconsuming (ca 60 minutes), the potential benefits are clear. Students became aware of the requirements they have to meet; their skills and qualities were taken seriously and their autonomy and self-regulation were encouraged by giving them the opportunity to plan their own work.

Team forming and planning of all assignments were followed by several sprints (Figure 1, step 8). A typical sprint took two weeks, with in total 4-6 lessons of 60 minutes each. Every lesson in a sprint started with a ceremony, called 'stand-up', in which teams discussed three questions: 1) What have you done? 2) Do you experience problems? And 3) What to do next (Schwaber \& Sutherland, 2017)? Every student contributed to this short standup meeting (Figure 1, step 9). Answering these questions aimed to evoke an appropriate response to the challenges of the project and moved students into the right direction making the project less overwhelming. A typical standup ceremony took 5 minutes at most and was followed by working on assignments, experiments, and exercises. Post-Its corresponding with the assignment were placed in the column 'doing' on the scrum board. When a task was accomplished the Post-It note was relocated to the column 'done'. Team-mates regularly discussed the progress. According to their sprint plan (step 6) they burned 'points'. Every two weeks each scrum team released an intermediate product, the sprint-release (Figure 1, step 10). Examples were: a written summary or a report of an experiment.

An intermediate product was always related to the final product, and its quality was checked in the review phase by the group and the product owner. Reviewing the quality in this educational context meant that the focus was on the chemistry concepts that were involved in the redox-chemistry project. Did students understand the chemistry concepts that were used to accomplish the assignments of the sprint? Were there any misconceptions present? A typical example of a review was a formative assessment provided by the teacher (Figure 1, step 11). Students answered questions individually about the chemistry concepts relevant for the project. They discussed their answers in their team or with the teacher. Both students and teacher got insight in the learning progress during the project. Students became aware of conceptual problems they had and could ask relevant questions to team members or teacher. In addition, teachers, could adjust their teaching, or, if necessary, intensify coaching of a particular scrum team. Explaining chemistry concepts and coaching were done throughout all stages. However, it was mostly driven by students' demand.

Before starting a new sprint cycle, scrum teams were invited to reflect on their collaboration and whether their efforts were in line with their own definition of done (Figure 1, step 12). This phase, called retrospective, was intended to improve the collaboration. Every scrum team was asked to formulate just one point of improvement to work on in the next sprint. Both the review and retrospective phase triggered students' reflections. A review focused on students' conceptual development, whereas the retrospective concentrated on the procedural aspects of Scrum methodology, such as collaboration among team members. In general, these systematic reflection phases contribute to adjustments during the course, which, while working on a project, can contribute to an agile learning environment and enhance students' self-regulation.

The Takeaway Energy consisted of three successive sprints of approximately two weeks each in which students improved their product and showed substantial growth in their conceptual development.

Finally, the scrum teams presented their final products, that is, a Galvanic cell, or a toy car, supplied with a citric acid battery, to each other and the product owner. Depending on school policy, the project was completed with an additional, summative assessment.

\section{Scrum Methodology as a Scaffold in Context-based Learning Environment}

A closer look at the roles, ceremonies and artefacts of Scrum methodology from a theoretical perspective provided insight in its potential as feasible motivational scaffold in context-based learning environments. In the educational literature scaffolding is defined as a form of support provided to students to solve a problem or to carry out a specific task that otherwise would be difficult to achieve (Sawyer, 2014). 
Originally, the concept of scaffolding was introduced by Wood, Bruner, and Ross (1976) referring to support provided by parents or teachers to help a child accomplish a learning task. Later the concept of scaffolding was extended to technical tools, including computer-based scaffolds, artefacts, resources and learning environments themselves. These tools were introduced to improve students' conceptual understanding, metacognition and selfregulation strategies (Land, Hannafin, \& Oliver, 2012). In addition, Belland, Kim, and Hannafin (2013, p. 247), stated that scaffolds could be beneficial to increase students' motivation.

Malik (2017) criticized the broadening of the scaffolding concept, by emphasizing that a framework or tool in itself cannot lead students towards self-regulation. Technological tools can only contribute to self-regulated learning if used in an appropriate way, that is, under guidance of a teacher.

Nevertheless, simply expecting the teacher to provide motivational, emotional and cognitive scaffolds to all individual students simultaneously, in a complex student-centered learning environment, is unreasonable. In the Netherlands, most secondary classes consist of 24 to 32 students with one teacher. Therefore, it is crucial to develop additional support to stimulate students' interest and their cognitive development, to direct their learning, to keep them on track and to control frustration (Belland et al., 2013). Tools, artefacts and learning environments can be helpful and indispensable instruments. We define scaffolds as support provided to students either by the teacher or by tools, procedures and artefacts to guide and improve students' learning process, stimulate self-regulation and autonomy, to guide them to achieve their learning objective and contributing to their engagement.

Appropriate scaffolds should be aligned with six factors found in the literature on motivating students (Belland et al., 2013). Establishing Task Value (ETV) is the first factor that contributes to students' motivation. Students' interest is fostered by teacher's introduction at the beginning of the context-based course. In the redox-chemistry course, the teacher connects the context to the personal lives of students by emphasizing that proper functioning of their smartphones depends on the transfer of chemical energy to electric energy. Usefulness refers to perceived acquisition of new skills that result from completing the task. The importance of doing well links to the perceived gains obtained from finishing the learning task and efforts refer to the extent to which participating in the task causes frustration or distracts the student from other more pleasant activities. Cole, Bergin, and Whittaker (2008) showed that a high task value is beneficial for learning achievement and contributes positively to students' efforts to perform well.

Promoting mastery goals (PMG) is the second factor to stimulate students' motivation. Mastery goals are associated with a range of positive outcomes, including persistence, deep processing, and intrinsic motivation (Hulleman, Schrager, Bodmann, \& Harackiewicz, 2010) and are promoted by providing feedback, promoting collaboration instead of competition, emphasizing rational goals and encouraging short term goals. The rather complex and comprehensive redox-chemistry project enforces collaboration among students. Scrum methodology provides ceremonies and tools to support this collaboration. Team forming is based on students' personal qualities, making every student valuable and accountable for achieving the ultimate objective. Working with brief, iterative sprints makes the huge learning task more manageable, which contributes to short term goals. Review and retrospective, at the end of each sprint cycle, provide informational feedback on respectively both conceptual development and procedural strategies. Students and teacher can adjust their approaches and explanations. Arranging rational goals with team-mates is stimulated during stand-up meetings, valuing points to assignments and agreement of how many points should be burned during a lesson.

The third factor is promoting belonging (PB). Experiencing a sense of belonging among teammates while performing a learning task contributes to intrinsic motivation (Deci \& Ryan, 2000). Estrangement among team members causes disengagement which will hinder effective collaboration (Kreijns, Kirschner, \& Vermeulen, 2013). There are at least three ways to enhance feelings of belonging: encouraging shared goals, accommodating social goals and co-constructing shared standards (Belland et al., 2013). In the redox-chemistry example, the ultimate objective is presented by the product owner. This could hinder embracement of the project by the students because they are not involved in establishing the project's aim. However, Scrum methodology requires groups to formulate shared goals. Every group is invited to formulate its own definition of done and a definition of fun. With their definition of done students show their shared commitment. A typical example of a definition of done drawn up by students is: "We have finished our work when all team members understand the chemistry concepts involved." Obviously, this definition shows their commitment. A definition of fun: every lesson we organize a short break in which we exchange a few jokes. Such rather simple, but self-appointed, shared goals can contribute to a positive climate in which groupmates experience feelings of mutual interdependence. Research has shown that students with positive interdependence exert greater effort and engage in higher quality interaction with group members than students without mutual interdependence (Johnson \& Johnson, 2008).

In addition, formulating shared goals can invoke social objectives such as feelings of personal responsibility and commitment: you cannot let your group go down. Tempelaar et al. (2013) found some evidence that teams, in which both social and shared goals are present, performed superior on self-assessments of group functioning compared to groups that only pursued shared goals. 
Another advantage of the definition of done is that it consists of criteria co-constructed by the groups themselves. This is a scaffolding strategy that contributes to students' feeling of belonging. The definition of done plays an important role during the retrospective phase at the end of each sprint cycle. The retrospective phase stimulates students to reflect on the quality of their collaboration.

Promoting emotion regulation (PER) is the fourth factor, contributing to students' motivation. Although context-based approaches, with their real-life question, can evoke enthusiasm and motivation among students, one should keep in mind that a learning environment is never perfect for all students. Thus, feelings of frustration, failure and confusion will arise at some point. Especially, when students are used to a classroom climate in which the teacher has all regulation functions, some students experience negative emotions during challenging and sometimes overwhelming demands of a context-based approach. Initial learning strategies often do not work and uncertainty about how to approach a learning task can cause negative emotions. Belland et al. (2013) described two strategies to promote emotion regulation to handle such feelings: highlight controllability of actions and promote reappraisal of failure. Controllability refers to students' perception of how they can control themselves, whereas reappraisal refers to the process of reflecting on the factors involved when students experience success or failure.

Both controllability and reappraisal can be promoted by the scrum retrospective. Within the scrum retrospective, students are encouraged to analyse what could have been done differently during the sprint. A short checklist, with questions regarding their mutual collaboration during the sprint and focussing on the quality of exchanging information among teammates, can act as a vivid reminder of their own definition of done. Students probably discover that failure was due to factors under their control. Thus, a scrum retrospective provides information which can be used by students to improve their learning process in the following sprint cycle. Teachers also play a crucial role in promoting emotion regulation by providing alternative explanations for feelings of confusion and frustration, especially when students judge failure as a reflection of self-worth or low ability. It is part of teachers' professionalism to highlight that failure is a natural part of the learning process and that making mistakes is allowed (Belland, Glazewski, \& Richardson, 2008). Personal, compassionate counselling how to overcome negative feelings and presenting accessible ways to deal with issues of frustration are important aspects of their job. Thus, although Scrum methodology provides scaffolds promoting emotion regulation, the role of the teacher as part of the scaffold (Malik, 2017) can only be underestimated.

Belland et al. (2013, p. 259) distinguished at least three different scaffolds promoting expectancies of success (PES, factor 5): promoting the perception of optimal challenge, supporting productive attribution, and enabling the identification of reliable processes. Students perceive a task as motivating if they expect that it is neither too easy nor too difficult. Thus, the experiments, exercises, and assignments provided in the product backlog must be aligned with students' abilities. Although students may be interested in their smartphones and even if they acknowledge that redox-chemistry affects their personal lives, they will not engage if they do not have an expectancy for success.

Therefore, besides a clear introduction of the context-based approach on redox-chemistry, a serious discussion between teacher and students about the requirements of the ultimate learning task is absolutely necessary. If students perceive that they can accomplish all assignments and achieve the ultimate objective of the course, they will experience the perception of optimal challenge.

In addition, educational research has shown that students' beliefs in their abilities to perform is influenced by feelings as luck, ability or failure (Weiner, 2010). Yeager and Dweck (2012) showed that it is beneficial for students to describe the cause of failure or success to effort and strategy use. Thus, teacher's feedback in the review phase or during the retrospective at the end of a sprint should include comments attributing students' success to their hard work and effective strategy use, and, if appropriate, lack of success to insufficient effort and poor strategy use. The review phase and the retrospective are natural moments to provide these comments. These ceremonies of Scrum methodology could facilitate reinforcement of expectancy of success. From the perspective of students, the review phase and the retrospective can contribute to identify effective strategies to achieve learning goals, respectively both on conceptual development and procedural aspects of their learning. Using strategies that turn out to be reliable, that is, lead to success, raise students' expectancies for success when they engage in similar learning tasks (Usher \& Pajares, 2008).

Factor 6 is promoting autonomy (PA). Although students are not allowed to choose their subject and their learning goals, they are free to develop their own planning, and to choose their own strategies to perform. This selfdirection promotes autonomy (Deci \& Ryan, 2000) and is seen as an important skill to promote success in life. Despite these benefits, having too many possibilities can cause frustration. There is a need for scaffolds balancing between too much autonomy and rigid procedures reducing freedom. Scrum methodology can provide such balance. This tool embeds procedures to schedule project segments in sprints and encourages students to reflect on the quality of their work. At the same time, groups have freedom to choose their own strategies. Additional advantages are the short time spans of the sprint cycle. Failures, bad strategies and conceptual problems are visible within one sprint cycle. Thus, adjustments can be made by both students and teacher. 
Table 1. Context-based approaches, Scrum methodology and their connection with scaffolds. Scaffolding guidelines are inspired by and adapted from: Belland et al. (2013, p. 250). Scaffolding strategies are connected to the motivational goals: Establishing Task Value (ETV); Promoting Mastery Goals (PMG); Promoting Belonging (PB); Promoting Emotion Regulation (PER); Promoting Expectancy for Success (PES); Promoting Autonomy (PA)

\begin{tabular}{|c|c|c|c|}
\hline $\begin{array}{l}\text { Scrum methodology } \\
\text { applied to context- } \\
\text { based approaches }\end{array}$ & Scaffolding guideline & Scaffolding strategies & $\begin{array}{l}\text { Motivation } \\
\text { factor(s) } \\
\text { involved }\end{array}$ \\
\hline \multirow[t]{2}{*}{$\begin{array}{l}\text { Real-world problem } \\
\text { (Figure 1, step 1) }\end{array}$} & Fostering interest & $\begin{array}{l}\text { A central question closely connected to students' personal life. } \\
\text { (Harackiewicz, Smith, \& Priniski, 2016) }\end{array}$ & ETV, PMG \\
\hline & Usefulness & $\begin{array}{l}\text { The teacher provides a rationale for relevance to personal current and } \\
\text { future life (Childs, Hayes, \& O'Dwyer, 2015). }\end{array}$ & ETV, PES \\
\hline $\begin{array}{l}\text { Scrum roles } \\
\text { a.Scrum master } \\
\text { (Figure 1, step 2) }\end{array}$ & Promoting shared goals & $\begin{array}{l}\text { Promoting team work by emphasizing mutual dependency and personal } \\
\text { responsibilities (Schwaber \& Sutherland, 2017). }\end{array}$ & PB \\
\hline \multirow[t]{2}{*}{$\begin{array}{l}\text { b.Team-mates } \\
\text { (Figure 1, step 2) }\end{array}$} & Sharing personal qualities & $\begin{array}{l}\text { Appreciation of qualities team-mates bring to the team (Delhij, van } \\
\text { Solingen, \& Wijnands, 2015). }\end{array}$ & PB \\
\hline & $\begin{array}{l}\text { Promoting cooperation rather } \\
\text { than competition }\end{array}$ & $\begin{array}{l}\text { Emphasizing the importance of cooperation rather than competition } \\
\text { (Hmelo-Silver, 2004). }\end{array}$ & PB \\
\hline \multirow[t]{3}{*}{$\begin{array}{l}\text { c. Product owner } \\
\text { (Figure 1, step 1) }\end{array}$} & $\begin{array}{l}\text { Promoting the perception of } \\
\text { optimal challenge }\end{array}$ & $\begin{array}{l}\text { Explaining students that they can accomplish the (scaffolded) task (Britner } \\
\text { \& Pajares, 2006). }\end{array}$ & PES \\
\hline & $\begin{array}{l}\text { Supporting productive } \\
\text { attribution }\end{array}$ & $\begin{array}{l}\text { The teacher provides productive attributional feedback during lesson, } \\
\text { review and retrospective (Delhij et al., 2015). }\end{array}$ & PER \\
\hline & Promoting appraisal of failure & $\begin{array}{l}\text { Suggesting alternative explanations for negative emotions students may } \\
\text { encounter while struggling with the learning task (Thoman, Smith, Brown, } \\
\text { Chase, \& Lee, 2013). }\end{array}$ & PES, PER, PB \\
\hline $\begin{array}{l}\text { Scrum ceremonies } \\
\text { a. Team forming } \\
\text { (Figure 1, step 2) } \\
\end{array}$ & $\begin{array}{l}\text { Promoting cooperation rather } \\
\text { than competition }\end{array}$ & $\begin{array}{l}\text { Emphasizing the importance of cooperation rather than competition } \\
\text { (Hmelo-Silver, 2004). }\end{array}$ & PMG. ETV, PES \\
\hline $\begin{array}{l}\text { b.Valuing items } \\
\text { (Figure 1, step 5) }\end{array}$ & Emphasizing rational goals & $\begin{array}{l}\text { Providing a ceremony to get a clear vision of all assignments (Schwaber \& } \\
\text { Sutherland, 2017). }\end{array}$ & PMG, PES \\
\hline \multirow[t]{2}{*}{$\begin{array}{l}\text { c. Stand-up } \\
\text { (Figure 1, step 9) }\end{array}$} & Encourage short term goals & $\begin{array}{l}\text { Prompting the creation of short-term goals within a sprint (Quintana et al., } \\
\text { 2004; Reiser, 2004). }\end{array}$ & $\begin{array}{l}\text { PMG, ETV, PES, } \\
\text { PA }\end{array}$ \\
\hline & Emphasizing rational goals & $\begin{array}{l}\text { Stimulating students to discuss progress of the project (Schwaber \& } \\
\text { Sutherland, 2017). }\end{array}$ & PMG \\
\hline $\begin{array}{l}\text { d.Sprint } \\
\text { (Figure 1, step 8) }\end{array}$ & Encourage short term goals & $\begin{array}{l}\text { Working on assignments provided in the product backlog (Schwaber \& } \\
\text { Sutherland, 2017). }\end{array}$ & PMG \\
\hline $\begin{array}{l}\text { e.Sprint release } \\
\text { (Figure 1, step 10) }\end{array}$ & Encourage short term goals & $\begin{array}{l}\text { Releasing an intermediate product to check its quality (Schwaber \& } \\
\text { Sutherland, 2017). }\end{array}$ & PMG \\
\hline $\begin{array}{l}\text { f. Review } \\
\text { (Figure 1, step 11) }\end{array}$ & $\begin{array}{l}\text { Informational feedback } \\
\text { Help students direct their own } \\
\text { learning }\end{array}$ & $\begin{array}{l}\text { Providing formative feedback on conceptual development (Shute, 2008). } \\
\text { Supporting to evaluate conceptual development (Shute, 2008). }\end{array}$ & $\begin{array}{l}\text { PMG, PES, ETV } \\
\text { PA }\end{array}$ \\
\hline \multirow[t]{3}{*}{$\begin{array}{l}\text { g.Retrospective } \\
\text { (Figure 1, step 12) }\end{array}$} & Informational feedback & $\begin{array}{l}\text { Reflect on the strategies used during the sprint cycle (Nisbet \& Shucksmith, } \\
\text { 2017). }\end{array}$ & PMG, PER, PA \\
\hline & Highlight controllability & $\begin{array}{l}\text { Explain that failures are a natural part of learning. Reflect on causes of past } \\
\text { failures, and what could have been done differently (Belland et al., 2008). }\end{array}$ & ETV, PMG, PES \\
\hline & Enabling reliable processes & $\begin{array}{l}\text { Encourage students to articulate strategy used and explain why this } \\
\text { strategy should (not) be reused (Mason \& Singh, 2016). }\end{array}$ & PES \\
\hline \multirow[t]{2}{*}{$\begin{array}{l}\text { h.Definition of done } \\
\text { (Figure 1, step 4) }\end{array}$} & Encouraging shared goals & $\begin{array}{l}\text { Shared goals are beneficial for students' motivation and support feelings of } \\
\text { responsibility (Tomasello, Carpenter, Call, Behne, \& Moll, 2005). }\end{array}$ & \\
\hline & $\begin{array}{l}\text { Co-constructing shared } \\
\text { standards }\end{array}$ & $\begin{array}{l}\text { Co-construction of standards to judge the quality of their work (Reeve, } \\
\text { 2009). }\end{array}$ & $\mathrm{PB}$ \\
\hline $\begin{array}{l}\text { i. Definition of fun } \\
\text { (Figure 1, step 4) }\end{array}$ & Encouraging shared goals & $\begin{array}{l}\text { Shared goals are beneficial for students' motivation and support feelings of } \\
\text { responsibility (Tomasello et al., 2005). }\end{array}$ & \\
\hline $\begin{array}{l}\text { Scrum artefacts } \\
\text { j. Scrum board } \\
\text { (Figure 1, step 7) } \\
\end{array}$ & $\begin{array}{l}\text { Help students direct their own } \\
\text { learning. }\end{array}$ & Creates overview over the tasks to be done (Schwaber \& Sutherland, 2017). & PA \\
\hline $\begin{array}{l}\text { k. Product backlog } \\
\text { (Figure } 1 \text { step } 3 \text { ) }\end{array}$ & Creating overview & Creates overview over the tasks to be done (Schwaber \& Sutherland, 2017). & PA \\
\hline $\begin{array}{l}\text { I. Burndown chart } \\
\text { (Figure 1, step 6) }\end{array}$ & Creating overview & $\begin{array}{l}\text { Encourages students to persist and visualizes their progress (Lazonder \& } \\
\text { Harmsen, 2016). }\end{array}$ & PES \\
\hline
\end{tabular}

Each motivational factor is connected to scaffolding guidelines and scaffolding strategies, which in turn can be found in the characteristics of Scrum methodology and the key features of context-based approaches (Table 1).

\section{Implementing Scrum Methodology in a Context-based Course: A Pilot Study}

From a theoretical point of view, Scrum methodology might be an appropriate framework to scaffold students' learning and motivation in context-based approaches. However, theory and practice can be quite disconnected. 
Therefore, an empirical pilot study was performed, intended to explore the initial experiences of veteran chemistry teachers with Scrum methodology. The research question underpinning this pilot study was: To what extent do veteran chemistry teachers experience Scrum methodology as an appropriate framework to scaffold students' learning with regard to six motivational factors?

\section{RESEARCH METHOD}

Participants were three veteran chemistry teachers. Before they implemented Scrum methodology in their chemistry classroom, they followed a professional development program, which focused on the background and the different components of the framework. After applying the framework to the teaching of a lesson series (i.e., on redox chemistry) the teachers were interviewed, which took for teacher 1 and 2 together 55 minutes and for teacher 340 minutes. The interviews were typescript verbatim and were sent to the teachers for approval. Relevant quotes were sorted out in four categories: real-world problem, scrum roles, scrum ceremonies and scrum artefacts. Subsequently, their responses were connected to the six motivational factors. The interviews were used as a first indication whether Scrum methodology might be beneficial for students' learning.

\section{RESULTS}

The six motivational factors are used to order relevant statements of the interviewees, to get insight in the potential benefits of Scrum methodology in a context-based chemistry course.

\section{Establishing Task Value (ETV)}

The teachers acknowledged that a real-world problem, closely connected to students' lives, can foster interest and that was what they noticed. However, they all emphasized that their focus was on the implementation of Scrum methodology itself. They experienced that starting it is a time-consuming and intense process for both students and teacher. Scrum comprises many components inducing considerable cognitive load. It takes time to become familiar with all scrum ceremonies, roles and artefacts. Although all teachers completed several sprints, they skipped the final assignment (build a toy car actuated by a citric acid battery) or substituted it by a less time-consuming assignment (build your own battery), due to evolved time constraints. Such implementation issues might affect other aspects involved in establishing task value, including students' perceptions of the usefulness of the learning task, the tools provided as well as perceived importance of doing well and efforts to be made to accomplish the task (Wigfield \& Eccles, 2000). However, according to teacher 1 the students experienced the usefulness of the scrum tools. His students responded positively on the reviews and understood the underlying redox-chemistry concepts better. Teacher 2 recognized that the ceremonies associated with Scrum methodology helped students to keep on track. He underlined that implementing Scrum methodology takes time. Despite this investment students' learning achievements were comparable with other years. Teacher 3 was sceptical. She reported frustration among her students. According to the students, ceremonies such as stand-up and group forming were unnecessary and had no added value. Her students preferred an individual approach and did not appreciate the collaborative character of the assignment. These differences suggest that the interplay between teacher and the students is an important prerequisite to establish students' task value. A challenging real-world question might foster interest. Complementing scrum ceremonies might be perceived as useful to decrease the complexity of the context-based course. However, such blended approaches do not guarantee that students' motivation and their learning achievement increase.

\section{Promoting Mastery Goals (PMG)}

Teacher 1 stressed the importance of team forming and especially the fact that students promised to deploy their personal qualities for their team. He reminded his students to take their promise seriously. According to teacher 2 the team forming ceremony contributed to the forming of heterogenous teams based on students' qualities instead of friendships, which he perceived as beneficial for students' learning. Teacher 3 reported that some students understood how they could manipulate the team forming ceremony, so they could form teams based on friendships. In addition, she experienced that several groups had difficulties to collaborate effectively, mainly because their timetables differed in one third of the lessons.

Teacher 2 emphasized that the product backlog is at the heart of Scrum methodology. It provides a clear picture of the learning goals, all assignments and the ultimate objective of the lesson series. A product backlog should be designed carefully. As time goes by a product backlog can be less specific, students can add their own ideas and assignments to achieve the ultimate objective. Teacher 1 agreed, whereas teacher 3 mentioned that she provided the students with a global overview of all assignments. 
Teacher 1 and 2 used formative assessments during the review ceremony. Although preparation of these assessments was time consuming, they experienced the advantages. Teacher 1 pointed out that formative assessments provided insight in students' progress for both teacher and students. Teacher 2 totally agreed and emphasized that developing appropriate questions (and their answers) for the formative assessments is time consuming. However, after all it is easier to adjust my teaching to the specific needs of my students. Teacher 3 explained that she used the review only at the end of the course, because of time constraints.

\section{Promoting Belonging (PB)}

Teacher 1 mentioned that especially scrum masters took their role seriously. They stimulated other team members to take their responsibility and created an atmosphere which stimulated their group to finish all their assignments together. Within this atmosphere he was able to provide feedback to his students on both conceptual and metacognitive issues. Students took their responsibility and formulated their own definition of done. An example: we all want to have at least $65 \%$ of all points on the final, summative assessment. Teacher 1 experienced that formulating shared goals positively affected students' learning behaviour. One of the groups agreed to finish a specific assignment in the last lesson before a short holiday. They persisted to complete their work although the official time schedule was over. Students showed great responsibility without external pushing of the teacher. Teacher 2 and 3 reported mixed results: some groups worked accurately, whereas other groups preferred a more traditional teaching style in which the teacher explains all concepts. Teacher 3 described additional organizational challenges, due to specific circumstances in her school, causing serious time constraints and problems with timetables.

\section{Promoting Emotion Regulation (PER)}

During a retrospective, teacher 1 invited his students to reflect on their learning process. He used the circlemethod consisting of two circles. In the inner circle students wrote down their successes, in the outer circle their challenges. He collected all statements and subsequently he discussed all points of improvement with the groups. Teacher 2 stressed that reflecting on learning progress is important. However, he was not satisfied with students' responses during the retrospective as he experienced that students often wrote down standard statements such as: 'we have to improve our homework'. Students of teacher 3 were invited to write down points of improvement. However, she mentioned that her students hardly worked on the intentions they formulated.

\section{Promoting Expectancy for Success (PES)}

Teacher 1 emphasized that the implementation of Scrum methodology in his lessons changed his teaching. Instead of only delivering content, he experienced that he had a more facilitating role in which he discussed conceptual issues as well as metacognitive aspects of learning, including collaboration issues and learning strategies. He missed telling stories about chemistry, which was one of the reasons why he wanted to become a chemistry teacher. At the start he experienced that students' self-efficacy decreased. However, after a few reviews and a successful summative assessment his students showed greater self-confidence. He underlined the importance of successes and the necessity of just in time feedback on conceptual issues and on learning strategies. Although a bit more cautious, teacher 2 responded in line with teacher 1 . He highlighted that Scrum methodology demands careful preparation of materials and skilful guidance of students. Teacher 3 emphasized that students showed resistance against Scrum methodology. They argued that designing a planning on a scrum board, and performing stand-ups delayed their learning unnecessarily. According to them the teacher should provide schedules and explain chemistry concepts.

\section{Promoting Autonomy (PA)}

All teachers emphasized that a scrum board creates overview for both students and teacher and that monitoring students' progress is easier. Groups have options to divide the learning activities among team members. They are free to design their own planning. Teacher 1 pointed out that - to his surprise - valuing items was no problem for his students. They were able to allocate points to the assignments faster than expected. Subsequently, the burndown chart helped them to get insight in their progress and to plan their work within a sprint cycle. Teacher 2 and 3 allocated the points to the assignments by themselves, mainly because they estimated that valuing items is too time consuming for students. 


\section{DISCUSSION}

The findings of the pilot study reveal a mixed picture. Both enthusiasm and scepticism are present among the participating teachers. Despite the theoretical connection between all the parts of Scrum methodology and factors that motivate students for learning, implementation of Scrum methodology is not a silver bullet to enhance students' achievement and motivation immediately and in all situations. Definitely, as becomes clear from the experiences of teacher 3, organizational issues in a school, for instance with timetables, as well as the relationship between teacher and students play a distinctive role. However, when these important conditions are met, then Scrum methodology both enriches teachers' repertoire and affects student learning. Teacher 1 reported that the ceremonies, roles and artefacts changed his teaching style, enabling him to discuss more aspects of the learning process with his students in an explicit and systematic way. He experienced that his instruction was more elaborated, that is, delivering content and explaining concepts were complemented with discussions concerning students' learning process. This suggests that Scrum methodology provides opportunities to promote emotion regulation and expectancies for success. In addition, all teachers mentioned that Scrum methodology increased students' feeling of autonomy, and that its ceremonies provided them with opportunities to enhance their feelings of belonging and to focus on their mastery goals.

\section{CONCLUSIONS}

Findings from the interviews as well as theoretical insights derived from motivation theories suggest that Scrum methodology provides a coherent set of scaffolds that enhances students' learning in context-based approaches at least at three different levels.

First, at the start of a context-based course, Scrum methodology enforces teacher and students to clarify its purpose. As a result, its complexity decreases, and the real-world issue becomes less overwhelming. Secondly, the reviews in particular elucidate which concepts play a key role. Thus, feelings of uncertainty, about what has to be learnt for end-of-term exams, are reduced. However, this requires a redesign of context-based approaches. Developing an engaging real-world question is not enough. It should be accompanied by carefully developed tasks and appropriate reviews. Thirdly, the Scrum ceremonies and artefacts facilitate students' collaboration and selfregulation. The systematic and explicit attention for these higher-order skills might prepare students better for their future lives in which life-long learning probably is an inherent part.

Obviously, the role of the teacher is invaluable in the implementation of both context-based approaches and Scrum methodology. It requires time and effort to become familiar with Scrum ceremonies and to develop appropriate tasks. Targeted supervision in well-designed professional development programs are necessary. However, the advantages of Scrum methodology would finally pay off.

\section{REFERENCES}

Belland, B. R., Glazewski, K. D., \& Richardson, J. C. (2008). A scaffolding framework to support the construction of evidence-based arguments among middle school students. Educational Technology Research and Development, 56(4), 401-422. https:// doi.org/10.1007/s11423-007-9074-1

Belland, B. R., Kim, C., \& Hannafin, M. J. (2013). A framework for designing scaffolds that improve motivation and cognition. Educational Psychologist, 48(4), 243-270. https://doi.org/10.1080/00461520.2013.838920

Bennett, J. (2017). Bringing science to life. In R. Taconis, P. den Brok, \& A. Pilot (Eds.), Teachers Creating ContextBased Learning Environments in Science (pp. 21-39). Rotterdam: Sense Publishers. https:/ / doi.org/10.1007/978-94-6300-684-2_2

Britner, S. L., \& Pajares, F. (2006). Sources of science self-efficacy beliefs of middle school students. Journal of Research in Science Teaching, 43(5), 485-499. https:// doi.org/10.1002/tea.20131

Childs, P. E., Hayes, S. M., \& O’Dwyer, A. (2015). Chemistry and everyday life: Relating secondary school chemistry to the current and future lives of students. In I. Eilks \& A. Hofstein (Eds.), Relevant Chemistry Education (pp. 33-54). Rotterdam: Sense Publisher. https:/ / doi.org/10.1007/978-94-6300-175-5_3

Cole, J. S., Bergin, D. A., \& Whittaker, T. A. (2008). Predicting student achievement for low stakes tests with effort and task value. Contemporary Educational Psychology, 33(4), 609-624. https:/ / doi.org/10.1016/j.cedpsych.2007.10.002

Cunningham, K. (2016). Variables that impact the implementation of project-based learning in high school science. Detroit: Wayne State University. 
De Jong, O., \& Treagust, D. (2003). The Teaching and Learning of Electrochemistry. In J. K. Gilbert, O. De Jong, R. Justi, D. F. Treagust, \& J. H. Van Driel (Eds.), Chemical Education: Towards Research-based Practice (pp. 317337). Dordrecht: Springer The Netherlands.

Deci, E. L., \& Ryan, R. M. (2000). The" what" and" why" of goal pursuits: Human needs and the self-determination of behavior. Psychological Inquiry, 11(4), 227-268. https://doi.org/10.1207/S15327965PLI1104_01

Delhij, A., van Solingen, R., \& Wijnands, W. (2015). The EduScrum Guide. Retrieved from http:/ / eduscrum.nl/en/file/CKFiles/The_eduScrum_Guide_EN_1.2.pdf

Gilbert, J. K. (2006). On the nature of "context" in chemical education. International Journal of Science Education, 28(9), 957-976. https:/ / doi.org/10.1080/09500690600702470

Harackiewicz, J. M., Smith, J. L., \& Priniski, S. J. (2016). Interest Matters. Policy Insights from the Behavioral and Brain Sciences, 3(2), 220-227. https:/ / doi.org/10.1177/2372732216655542

Harris, C. J., \& Rooks, D. L. (2010). Managing inquiry-based science: Challenges in enacting complex science instruction in elementary and middle school classrooms. Journal of Science Teacher Education, 21(2), 227-240. https:// doi.org/10.1007/s10972-009-9172-5

Hmelo-Silver, C. E. (2004). Problem-based learning: What and how do students learn? Educational Psychology Review, 16(3), 235-266. https:/ / doi.org/10.1023/B:EDPR.0000034022.16470.f3

Hmelo-Silver, C. E., Duncan, R. G., \& Chinn, C. A. (2007). Scaffolding and achievement in problem-based and inquiry learning: A response to Kirschner, Sweller, and Clark (2006). Educational Psychologist, 42(2), 99-107. https:// doi.org/10.1080/00461520701263368

Hulleman, C. S., Schrager, S. M., Bodmann, S. M., \& Harackiewicz, J. M. (2010). A meta-analytic review of achievement goal measures: Different labels for the same constructs or different constructs with similar labels? Psychological Bulletin, 136(3), 422. https:/ / doi.org/10.1037/a0018947

Johnson, D. W., \& Johnson, R. T. (2008). Social Interdependence Theory and Cooperative Learning: The Teacher's Role. In R. M. Gillies, A. F. Ashman, \& J. Terwel (Eds.), The Teacher's Role in Implementing Cooperative Learning in the Classroom (pp. 9-37). Boston, MA: Springer US. https:/ / doi.org/10.1007/978-0-387-70892-8_1

King, D., \& Ritchie, S. M. (2012). Learning science through real-world contexts. In B. Fraser, K. Tobin, \& C. McRobbie (Eds.), Second International Handbook of Science Education (pp. 69-79). Dordrecht: Springer The Netherlands. https:/ / doi.org/10.1007/978-1-4020-9041-7_6

Kreijns, K., Kirschner, P. A., \& Vermeulen, M. (2013). Social aspects of CSCL environments: A research framework. Educational Psychologist, 48(4), 229-242. https:/ / doi.org/10.1080/00461520.2012.750225

Land, S. M., Hannafin, M. J., \& Oliver, K. (2012). Student-centered learning environments. In D. Jonassen \& S. M. Land (Eds.), Theoretical Foundations of Learning Environments. Second Edition (pp. 3-21). New York: Routledge. https:// doi.org/10.4324/9780203813799

Lazonder, A. W., \& Harmsen, R. (2016). Meta-analysis of inquiry-based learning. Review of Educational Research, 86(3), 681-718. https://doi.org/10.3102/0034654315627366

Malik, S. A. (2017). Revisiting and re-representing scaffolding: The two gradient model. Cogent Education, 4(1), 1331533. https:// doi.org/10.1080/2331186X.2017.1331533

Mason, A. J., \& Singh, C. (2016). Impact of guided reflection with peers on the development of effective problem solving strategies and physics learning. The Physics Teacher, 54(5), 295-299. https://doi.org/10.1119/1.4947159

Mayer, R. E. (2004). Should there be a three-strikes rule against pure discovery learning? American Psychologist, 59(1), 14. https:/ / doi.org/10.1037/0003-066X.59.1.14

Mergendoller, J. R., Markham, T., Ravitz, J., \& Larmer, J. (2006). Pervasive Management of Project Based Learning: Teachers as Guides and Facilitators. In Handbook of classroom management: Research, practice, and contemporary issues. (pp. 583-615). Mahwah, NJ, US: Lawrence Erlbaum.

Nentwig, P. M., Demuth, R., Parchmann, I., Ralle, B., \& Gräsel, C. (2007). Chemie im Kontext: Situating learning in relevant contexts while systematically developing basic chemical concepts. Journal of Chemical Education, 84(9), 1439. https:/ / doi.org/10.1021/ed084p1439

Nisbet, J., \& Shucksmith, J. (2017). Learning strategies. London: Routledge. https:// doi.org/10.4324/9781315188652

Parchmann, I., Broman, K., Busker, M., \& Rudnik, J. (2015). Context-Based Teaching and Learning on School and University Level. In J. Garcia-Martinez \& E. Serrano-Torregrosa (Eds.), Chemistry Education: Best Practices, Innovative Strategies and New Technologies (pp. 259-278). Weinheim: Wiley-VCH. https://doi.org/10.1002/9783527679300.ch10 
Pilot, A., \& Bulte, A. M. W. (2006). Why Do You "Need to Know"? Context-based education. International Journal of Science Education, 28(9), 953-956. https:/ / doi.org/10.1080/09500690600702462

Quintana, C., Reiser, B. J., Davis, E. A., Krajcik, J., Fretz, E., Duncan, R. G., . . Soloway, E. (2004). A scaffolding design Framework for software to support science inquiry. The Journal of the Learning Sciences, 13(3), 337-386. https://doi.org/10.1207/s15327809j1s1303_4

Reeve, J. (2009). Why teachers adopt a controlling motivating style toward students and how they can become more autonomy supportive. Educational Psychologist, 44(3), 159-175. https:/ / doi.org/10.1080/00461520903028990

Reiser, B. J. (2004). Scaffolding complex learning: The mechanisms of structuring and problematizing student work. The Journal of the Learning Sciences, 13(3), 273-304. https:/ / doi.org/10.1207/s15327809j1s1303_2

Rubin, K. S. (2012). Essential Scrum: A practical guide to the most popular Agile process. New York: Addison-Wesley.

Savelsbergh, E. R., Prins, G. T., Rietbergen, C., Fechner, S., Vaessen, B. E., Draijer, J. M., \& Bakker, A. (2016). Effects of innovative science and mathematics teaching on student attitudes and achievement: A meta-analytic study. Educational Research Review, 19, 158-172. https:// doi.org/10.1016/j.edurev.2016.07.003

Sawyer, R. K. (2014). Introduction: The new science of learning. In R. K. Sawyer (Ed.), The Cambridge Handbook of the Learning Sciences (pp. 27-55). Cambridge: Cambridge University Press. https://doi.org/10.1017/CBO9781139519526

Schwaber, K., \& Sutherland, J. (2017). The Scrum Guide. The Definitive Guide to Scrum: The Rules of the Game. Retrieved from https://www.scrumguides.org/scrum-guide.html

Scott, E., Rodríguez, G., Soria, Á., \& Campo, M. (2016). Towards better Scrum learning using learning styles. Journal of Systems and Software, 111, 242-253. https:/ / doi.org/10.1016/j.jss.2015.10.022

Sevian, H., Dori, Y. J., \& Parchmann, I. (2018). How does STEM context-based learning work: what we know and what we still do not know. International Journal of Science Education, 40(10), 1095-1107. https:/ / doi.org/10.1080/09500693.2018.1470346

Shute, V. J. (2008). Focus on formative feedback. Review of Educational Research, 78(1), 153-189. https:// doi.org/10.3102/0034654307313795

Tempelaar, D. T., Wosnitza, M., Volet, S., Rienties, B., Giesbers, B., \& Gijselaers, W. H. (2013). The role of self-and social directed goals in a problem-based, collaborative learning context. Higher Education, 66(2), 253-267. https:/ / doi.org/10.1007/s10734-012-9602-8

Thoman, D. B., Smith, J. L., Brown, E. R., Chase, J., \& Lee, J. Y. K. (2013). Beyond performance: A motivational experiences model of stereotype threat. Educational Psychology Review, 25(2), 211-243. https:// doi.org/10.1007/s10648-013-9219-1

Tomasello, M., Carpenter, M., Call, J., Behne, T., \& Moll, H. (2005). In search of the uniquely human. Behavioral and Brain Sciences, 28(5), 721-727. https:/ / doi.org/10.1017/S0140525X05540123

Usher, E. L., \& Pajares, F. (2008). Sources of self-efficacy in school: Critical review of the literature and future directions. Review of Educational Research, 78(4), 751-796. https:/ / doi.org/10.3102/0034654308321456

Vos, M. A. J., Taconis, R., Jochems, W. M. G., \& Pilot, A. (2016). Interaction between Teachers and Teaching Materials. In Teachers Creating Context-Based Learning Environments in Science (pp. 125-143). Rotterdam: Sense Publishers. https:/ / doi.org/10.1007/978-94-6300-684-2_8

Weiner, B. (2010). The development of an attribution-based theory of motivation: A history of ideas. Educational Psychologist, 45(1), 28-36. https:/ / doi.org/10.1080/00461520903433596

Wigfield, A., \& Eccles, J. S. (2000). Expectancy-value theory of achievement motivation. Contemporary Educational Psychology, 25(1), 68-81. https:/ / doi.org/10.1006/ceps.1999.1015

Wood, D., Bruner, J. S., \& Ross, G. (1976). The role of tutoring in problem solving. Journal of Child Psychology and Psychiatry, 17(2), 89-100. https:/ / doi.org/10.1111/j.1469-7610.1976.tb00381.x

Yeager, D. S., \& Dweck, C. S. (2012). Mindsets that promote resilience: When students believe that personal characteristics can be developed. Educational Psychologist, 47(4), 302-314. https:/ / doi.org/10.1080/00461520.2012.722805

\section{http://www.ejmste.com}

